Research Article

\title{
Safety Management in Sea Reclamation Construction: A Case Study of Sanya Airport, China
}

\author{
Jinchao Ma, ${ }^{1}$ Wei Zhong ${ }^{D},{ }^{1}$ and Xiaoliu $\mathrm{Zhu}^{2}$ \\ ${ }^{1}$ School of Management, Tianjin University of Technology, Tianjin 300384, China \\ ${ }^{2}$ China Construction Sixth Engineering Division Corp., South China Branch, Tianjin, China \\ Correspondence should be addressed to Wei Zhong; zhongwei@tjut.edu.cn
}

Received 8 November 2019; Revised 3 June 2020; Accepted 18 June 2020; Published 16 July 2020

Academic Editor: Rafael J. Bergillos

Copyright (c) 2020 Jinchao Ma et al. This is an open access article distributed under the Creative Commons Attribution License, which permits unrestricted use, distribution, and reproduction in any medium, provided the original work is properly cited.

Urbanization has increased the burden on land resources. Artificial island construction has been proven as an effective method for addressing these land resource problems; however, few studies have been conducted on the safety of sea reclamation construction. This paper proposes a systemic approach to the complete safety management process in sea reclamation engineering, including safety system design, analysis, control, and assessment, using the Sanya Sea Reclamation Airport, Hainan Province, China, as a case study. A total of 145 steel cylinders must be vibrated and sunk into the seafloor to create a $9 \mathrm{~km}$ quay wall. Owing to their large size, the steel cylinders have been divided into different segments, and an assembly jig is employed to ensure a safe production process. Considering the hazardous working environment in sea reclamation construction, a numerical analysis is conducted to investigate the safe repertory of these steel cylinders and verify the reliability of the selected scheme for their transportation. Finally, control measures are adopted to ensure a safe vibration and sinking procedure for the steel cylinders. The proposed approach could be used to provide safety management guidelines for artificial island engineering and construction.

\section{Introduction}

Owing to the rapid increase in urbanization and urban sprawl, the area of land available to address the myriad needs of large urban centers has been decreasing; consequently, the development and utilization of marine space have also attracted considerable attention in recent years. To alleviate the problem of increasing urban space volumes, artificial islands are being used widely and increasingly as they have little impact on the marine and coastal environments. In this sense, quay walls play a crucial role in sea reclamation construction. Currently, caisson revetments, riprap structures, and steel cylinders are among the most commonly used methods in the development of quay wall structures. Compared to other structures, steel cylinders require less earthwork excavation and filling; moreover, construction using steel cylinders is rapid and produces little environmental pollution under complex working environments at sea. Therefore, steel cylinders have become the primary choice in sea reclamation constructions [1]. During the marine construction process, safety accidents occur frequently because of the numerous risk factors involved in these complex marine environments, which pose tremendous danger to marine engineering structures [2].

Quality, time, and budget play significant roles in project management; measures should be taken to balance their key functions [3]. Furthermore, many projects operate on tight working schedules and the occurrence of construction accidents may lead to delays in their completion [4]. An increasing number of studies have focused on safety management in marine engineering. Owing to their lack of safety awareness, humans are prone to participate in unsafe activities. Research has indicated that numerous accidents in marine construction projects can be attributed to human error, which may lead to serious consequences [5-7]. To reduce marine accidents during sea reclamation construction, it is important to concentrate on the different categories of human error $[8,9]$.

Sea transportation of marine construction materials and equipment has increased gradually, and the safety of ships 
has become a significant concern. To evaluate the capability of marine emergency evacuation system schemes accurately, Tong et al. [10] presented a scheduling simulation method that integrates evacuation demand analysis and marine network analysis. Owing to poor sea routes, many ship accidents have been attributed to collisions [11, 12], grounding [13], or fire/explosions [14]. Such cases have been carefully analyzed to help safety practitioners avoid similar accidents [15]. Moreover, novel technological innovations have been introduced in the safety management protocols of marine construction [16]. Grabowski et al. [17] developed a safety-critical system by employing wearable, immersive, augmented reality (WIAR) technology to improve decisionmaking in marine navigation. Furthermore, Tan et al. [18] proposed a digital construction system integrating building information modeling (BIM) and geographical information system (GIS) to effectively obtain optimal schemes of disassembling topsides for multiple offshore platforms; currently, this is widely used in marine construction. Three intelligent algorithms were employed in that system to solve the lift panning optimization problem. In general, previous studies have demonstrated independent safety management approaches in marine engineering, but their consideration of steel cylinders in marine construction is limited. Therefore, a comprehensive methodology of the overall safety management process in sea reclamation engineering must be developed to fill this research gap.

The quay wall of the Sanya Sea Reclamation Airport (SSRA), which has a total length of $9 \mathrm{~km}$, is known to be the largest steel cylinder structure used in an artificial island in China. To construct an artificial island, steel cylinders are required to vibrate and sink into the seafloor. Owing to the complex and hazardous working environment at sea, a poor location system is likely to be produced and causes construction damage. To achieve successful steel cylinder vibration and sinking, a systemic approach for the complete safety management process is proposed, including safety system design, analysis, control, and evaluation. The results of this study could be used to provide guidelines for safety management in artificial island engineering and construction.

\section{Project Profile}

SSRA is a sea reclamation airport, located in the Hainan province, China, with a total area of approximately $24 \mathrm{~km}^{2}$ and an offshore distance of approximately $3.6 \mathrm{~km}$, as seen in Figure 1. It is located between Nanshan Guanyin and Ultima Thule in the Southern China Sea. The average water depth on the artificial island is $20-30 \mathrm{~m}$. SSRA was constructed to meet the growing requirements of international trade cooperation and the development of surrounding countries. It can accommodate almost 60 million passengers annually, and its total construction cost was 8.7 billion yuan.

Known as the "super-large" steel cylinder construction of China, the steel cylinder quay wall structure contains 145 steel cylinders for a total length of $9 \mathrm{~km}$, as seen in Figure 2. Steel cylinders are arranged along the shore wall front line on the southern side of the artificial island. The steel cylinders have a diameter of $30 \mathrm{~m}$ and a thickness of $22 \mathrm{~mm}$. In addition, the height of the steel cylinder ranges from 25 to $39 \mathrm{~m}$ with a weight of approximately 500-800 t. The distance between steel cylinders is $3 \mathrm{~m}$, and the steel cylinders are connected via auxiliary cells. The weight of an auxiliary cell is $65-105 \mathrm{t}$, and its thickness is $20 \mathrm{~mm}$ on the seaside and $16 \mathrm{~mm}$ on the continental side. Both sides of the auxiliary cell's subgrid curved steel plate are welded with a $t$-type lock, which is connected with the wide mortise welded on the steel cylinder. Q345B steel is selected for the steel cylinder, auxiliary cell, and wide mortise. T250 $\times 200 \times 10 \times 16$ steel is selected for the longitudinal reinforcing rib, and a PL16 strip is employed for the transverse reinforcing rib. Q235B steel is selected for the longitudinal and transverse reinforcing ribs. The designed service life of the steel cylinder is 100 years. ZF series marine engineering special epoxy heavy anticorrosive coating is employed to protect the steel cylinders from corrosion.

2.1. Environmental Impact Assessment. The environmental impact assessment scope in relation to Sanya Airport is depicted in Figure 3, and the SSRA construction project is located in the Hongtang Bay coastal industrial and urban zones. The scope contains three tourism zones, two fishery zones, a marine protected zone, and a seaport. It is worth noting that, in this scope, there are three coral reef habitats along the shoreline, namely, a coral reef marine protected area and two coral reef habitats.

To comprehensively assess the environmental impact of SSRA construction, hydrodynamics, seawater quality, erosion, environmental deposition, and the health of the marine ecosystem were examined. The results are presented in Table 1.

2.2. Hydrodynamic Impact Assessment. The hydrodynamics of the Sanya Airport construction project was examined by analyzing changes in tidal current speed. Figure 4 shows that tidal current speed changes will mainly occur in the Hongtang Bay industrial and urban sea zones, and that the hydrodynamics of other critical surrounding zones will not change significantly.

2.3. Seawater Quality Impact Assessment. In the Sanya Airport construction process, during dredging and riprapping of the bank revetment foundation trench, a massive effusion in overflow vent leads to suspended solids, which negatively impacts seawater quality. According to numerical simulation results, these suspended solids will mainly be constrained to the Hongtang Bay industrial and urban zones and will not impact the seawater quality of other critical surrounding zones (Figure 5).

\subsection{Erosion and Deposition Environmental Impact} Assessment. Seabed and coastline evolution were examined to investigate the erosion and deposition environmental impact due to the construction of Sanya Airport. Figure 6 shows that the largest annual seabed deposition thickness 


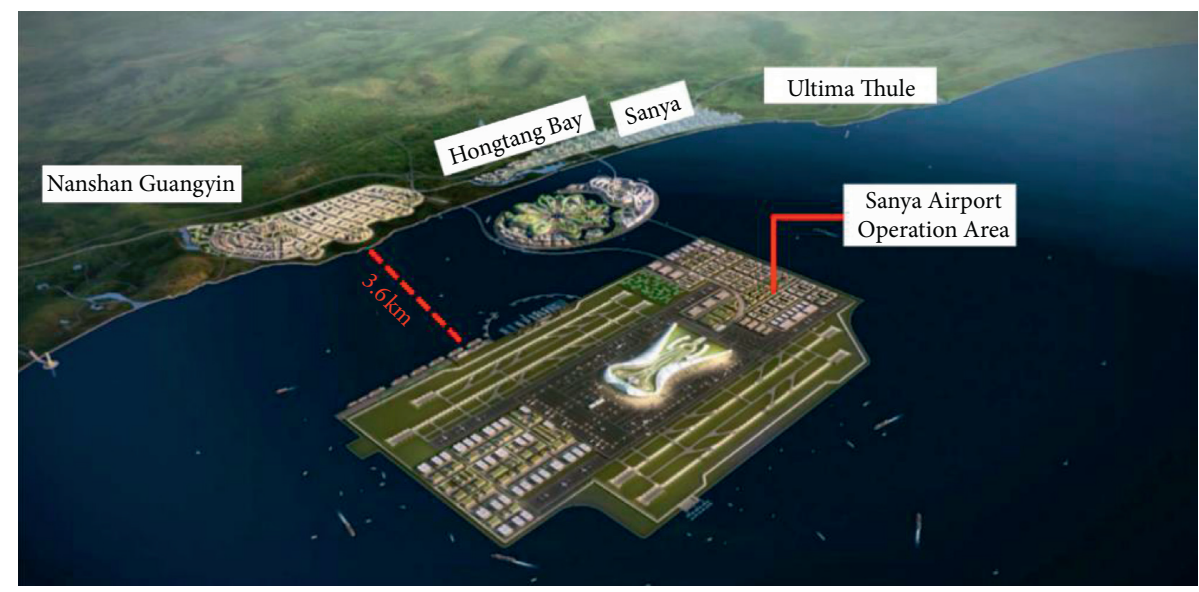

FIgURE 1: SSRA location.

will occur in the Hongtang Bay industrial and urban zones, while other zones will remain relatively unaffected.

Tables 2 and 3 show the shoreline evolution before and after SSRA. Based on the comparison from Sanmei Bay to Taling Zone, coastline deposition amounts will extend $124 \mathrm{~m}$ and the coastline thickness will increase $4.1 \mathrm{~m}$ annually during the next 30 years following construction. Hongtang Port is in the center of Sanmei Bay and Taling Zone, so it is expected that it will be impacted. But taking into consideration that Hongtang Bay is a port, the influence should be limited.

2.5. Marine Ecosystem Impact Assessment. The habitat conditions of benthos, fish eggs, larvae, photosynthesis, and coral reef were examined to investigate the marine ecosystem impact of SSRA construction. Sea reclamation projects completely change the environmental conditions of the sea area around the construction site, which have an adverse impact on benthos. The majority of them will be buried, covered, and eventually die. The increase in suspended solid concentration will also affect seawater quality in a negative manner, leading to fish eggs and larvae death. Therefore, ecological compensation measures need to be implemented to ease this situation. Suspended solids will also increase the turbidity of the surrounding sea area, reducing the photosynthesis rate of phytoplankton. But this impact is expected to have a short-term environmental effect. After construction, suspended solid concentration will gradually decrease. Consequently, the phytoplankton community will start rebuilding within a few weeks until eventually recovering to their original level.

Coral reefs were distributed in the Sanya Coral Reef Marine Protected Zone and the area from Sanmei Bay to Taling Zone. According to the hydrodynamics, suspended solids, and deposition thickness assessments, coral reefs in the marine protected zone will not be significantly impacted. However, coral reefs in the area comprising Sanmei Bay to Taling zone will be impacted. Due to coastline deposition in this area, six hectares of habitat will be occupied, which will adversely impact coral reefs.
2.6. Noise Contamination Assessment. Environmental health impact assessment focuses on environmental impact especially on human being. During SSRA, noise may influence human health, so an investigation should be performed during the SSRA construction process to assess noise contamination levels. Table 4 depicts the noise value of various construction machines. Based on these data, the noise influence range of these machines can be calculated:

$$
L_{i}=L_{0}-20 \lg \left(\frac{r_{i}}{r_{0}}\right) \text {, }
$$

where $L_{i}$ is the noise value of $r_{i}, L_{0}$ is the noise value of $r_{0}, r_{i}$ is the distance from prediction point to noise source, and $r_{0}$ is the noise monitoring distance.

Table 5 shows that daytime construction noise should have a range of at least $89 \mathrm{~m}$ from construction site to human residence and at least $500 \mathrm{~m}$ at night. Considering that the nearest human residence to the construction site is at a distance of $4.6 \mathrm{~km}$, it is determined that it meets the environmental noise emission standard requirements for construction site boundary (GB12523 2011). Therefore, noise will not impact human healthy in a negative manner.

\section{Safety System Design}

The production and transportation of steel cylinders play a significant role in the security management of sea reclamation engineering projects, especially under the complex oceanic conditions. As shown in Figure 7, the large steel cylinders were divided into several small segments to facilitate their processing at the factory. Then, these segments are transported to a wharf and assembled using an assembly jig and lifting machines. Finally, the assembled steel cylinders are transported to the construction site for further work. Therefore, the design of the assembly jig and the steel cylinder segments should be considered in detail to ensure a successful process.

3.1. Design of Steel Cylinder Segments. To address the challenges of construction and to increase construction efficiency, the steel cylinders used for the SSRA quay wall were 


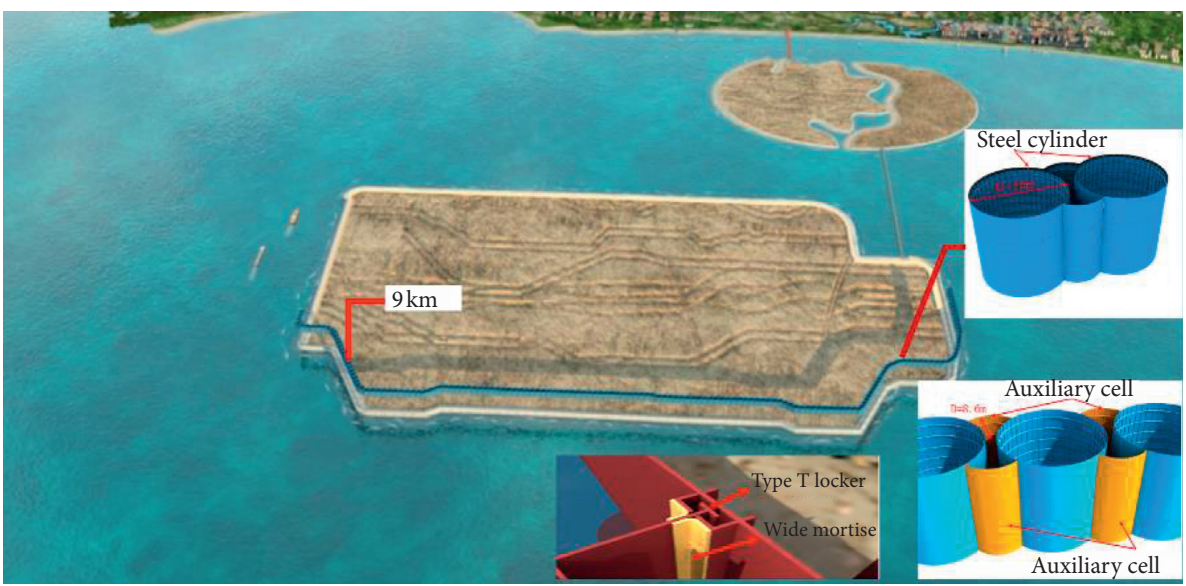

Figure 2: Steel cylinder quay wall.

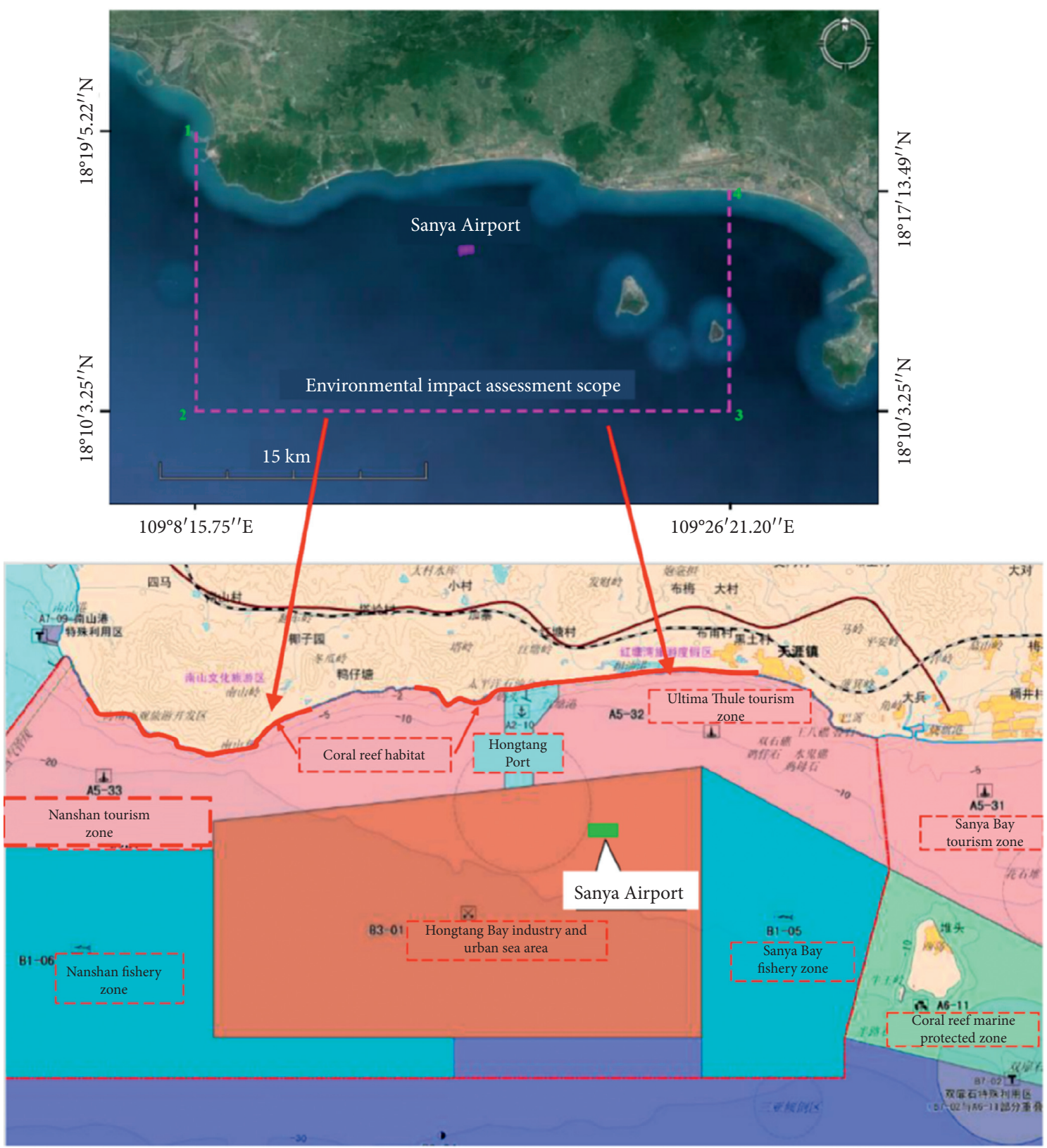

FIgURE 3: Environmental impact assessment scope of SSRA. 
TABLE 1: SSRA environmental impact assessment.

\begin{tabular}{|c|c|c|}
\hline Environmental impact indicator & Assessment item & Impact degree \\
\hline Hydrodynamics & Tidal current speed change & No impact \\
\hline Seawater quality & Suspended solids & No impact \\
\hline \multirow{2}{*}{ Erosion and deposition environment } & Seabed evolution & No impact \\
\hline & Coastline evolution & Hongtang Bay will suffer limited impact \\
\hline \multirow{4}{*}{ Marine ecosystem } & Benthos & Benthos will be impacted \\
\hline & Fish eggs and larvae & Fish eggs and larvae will be impacted \\
\hline & Photosynthesis & Short-term impact and will recover soon \\
\hline & Coral reef & 6 hectares of coral reef along the coastline will be impacted \\
\hline
\end{tabular}

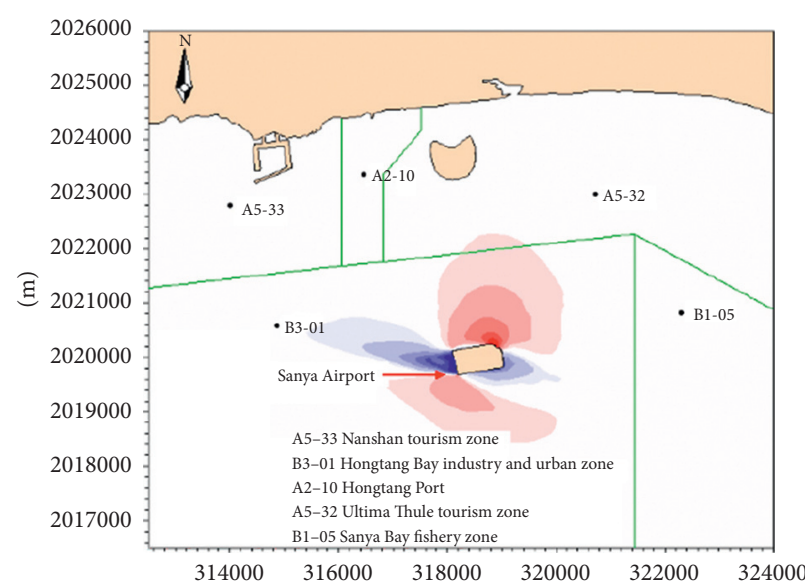

(m)

Current speed change $(\mathrm{m} / \mathrm{s})$

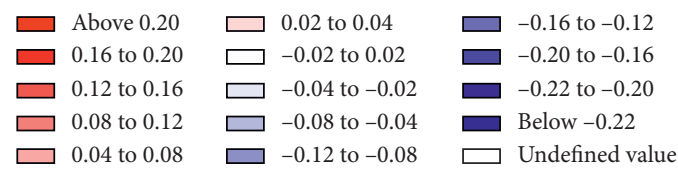

(a)

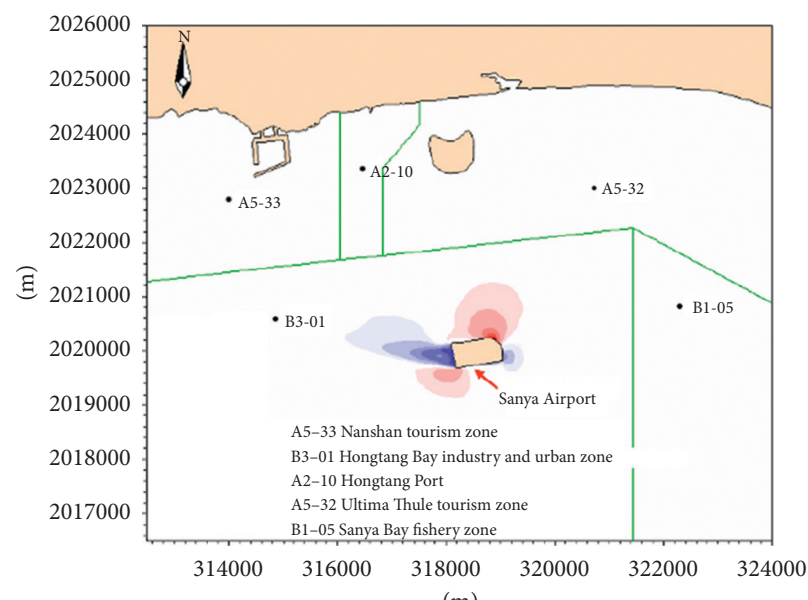

(m)

Current speed change $(\mathrm{m} / \mathrm{s})$

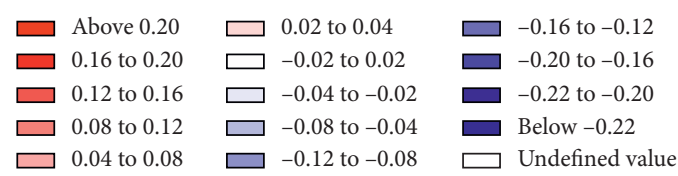

(c)

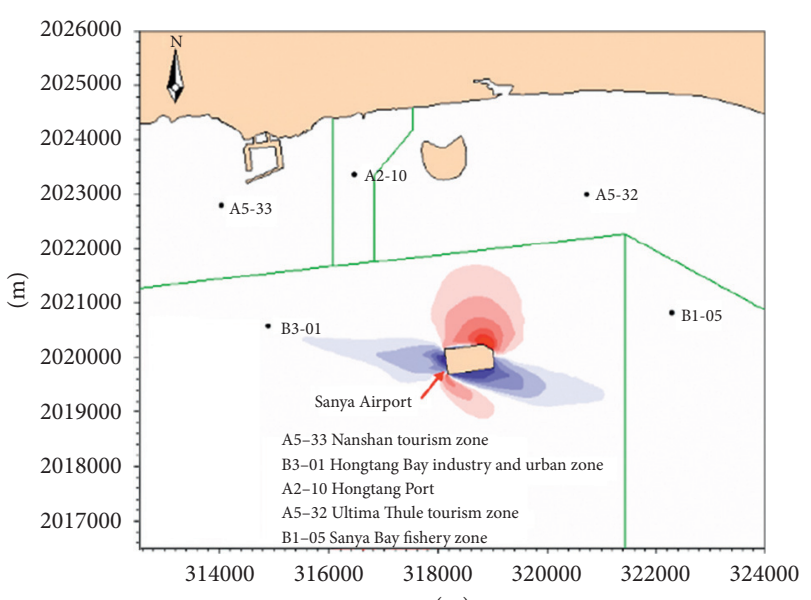

(m)

Current speed change $(\mathrm{m} / \mathrm{s})$

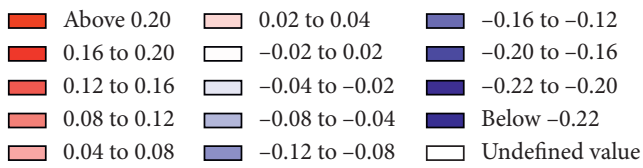

(b)

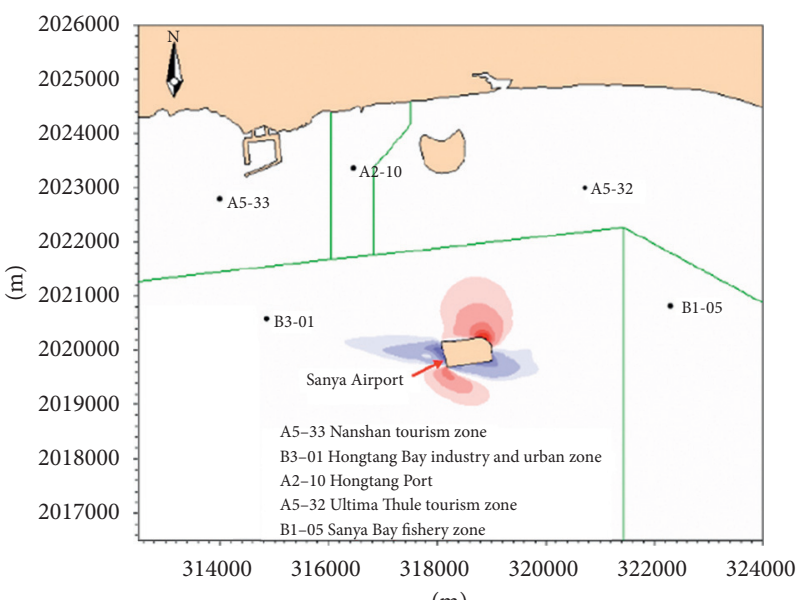

(m)

Current speed change $(\mathrm{m} / \mathrm{s})$

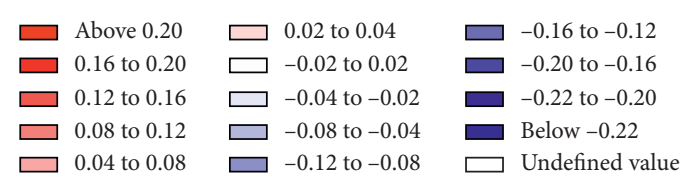

(d)

Figure 4: Tidal current speed change: (a) high tide rising; (b) high tide ebbing; (c) neap tide rising; (d) neap tide ebbing. 


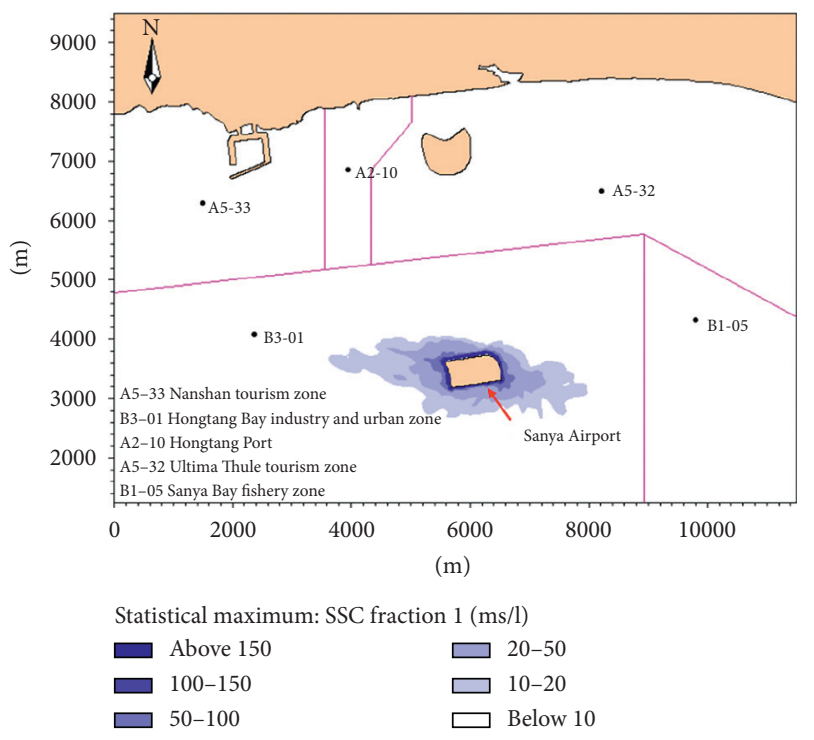

Figure 5: Statistical maximum fraction of suspended solid diffusion.

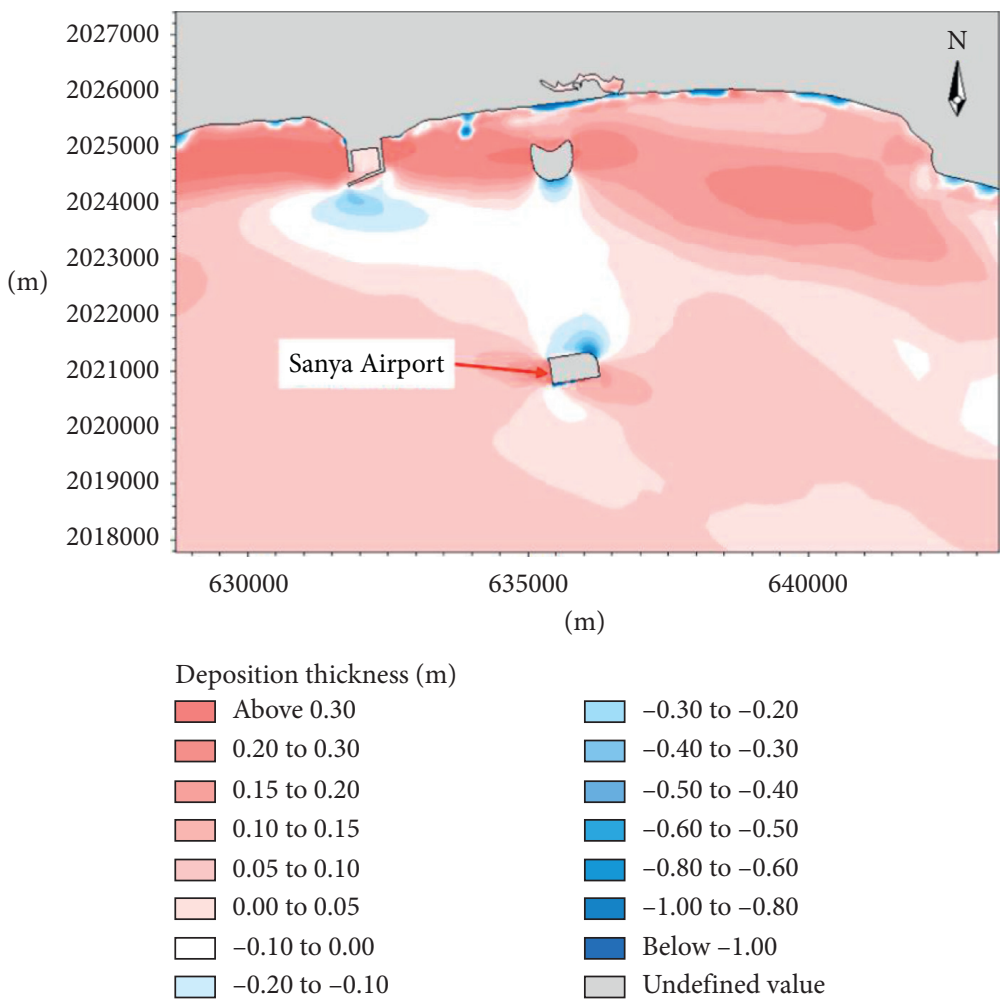

FIgURE 6: Annual seabed erosion and deposition distribution.

vertically divided circumferentially into eight units and horizontally into two segments (the upper and lower sections), as shown in Figure 8. The length of the upper and lower sections is 12.7 and $20.8 \mathrm{~m}$, respectively.

To avoid weld overlapping, the eight segments of the steel cylinder lower section are divided into two types (type A and type B), as shown in Figure 9(a). Type A comprises six $3.2 \mathrm{~m}$ wide plate units on the bottom side of the barrel and one $1.6 \mathrm{~m}$ wide plate unit on the top of the barrel, as shown in Figure 9(b). Type B is composed of six $3.2 \mathrm{~m}$ wide plate units and one $1.6 \mathrm{~m}$ wide plate unit on the bottom side of the barrel, as shown in Figure 9(c).

Meanwhile, the eight segments of the steel cylinder upper section are also divided into two types (type $\mathrm{C}$ and type D), as shown in Figure 10(a). Type C comprises three $3.2 \mathrm{~m}$ wide plate units on the bottom side of the barrel and one $1.6 \mathrm{~m}$ wide plate unit on the top side of the barrel, as shown in Figure 10(b). Type D is composed of three $3.2 \mathrm{~m}$ 
TABLE 2: Shoreline evolution before SSRA.

\begin{tabular}{lcc}
\hline Shoreline name & Maximum shoreline recession or advance length in 30 years $(\mathrm{m})$ & Annual average erosion or deposition thickness $(\mathrm{m})$ \\
\hline Nanshan Cape & -19 & +0.6 \\
Nanshan Guanyin & - & - \\
Sanmei Bay & -20 & +0.7 \\
Taling Zone & & \\
You Wharf & +6 & +0.2 \\
Danyou Bay & - & - \\
Tianya Town & Ultima Thule Zone &
\end{tabular}

Note: “+” represents shoreline advance length or deposition thickness; “-” represents shoreline recession length or erosion thickness.

TABLE 3: Shoreline evolution after SSRA.

\begin{tabular}{lcc}
\hline Shoreline name & Maximum shoreline recession or advance length in 30 years $(\mathrm{m})$ & Annual average erosion or deposition thickness (m) \\
\hline Nanshan Cape & -36 & +1.2 \\
Nanshan Guanyin & & +4.1 \\
Sanmei Bay & +124 & +1.7 \\
Taling Zone & & \\
You Wharf & +50 & +1.4 \\
Danyou Bay & -42 & +0.6 \\
Tianya Town & -18 & \\
Ultima Thule Zone &
\end{tabular}

Note: "+" represents shoreline advance length or deposition thickness; "-" represents shoreline recession length or erosion thickness.

TABLE 4: Noise values of construction machines.

\begin{tabular}{|c|c|c|}
\hline Noise source & $\begin{array}{l}\text { Noise monitoring distance } \\
(\mathrm{m})\end{array}$ & $\begin{array}{l}\text { Noise value } \\
(\mathrm{dB}(\mathrm{A}))\end{array}$ \\
\hline Piling machine & 5 & 95 \\
\hline Bulldozer & 10 & 84 \\
\hline $\begin{array}{l}\text { Loader } \\
\text { machine }\end{array}$ & 10 & 81 \\
\hline $\begin{array}{l}\text { Cement } \\
\text { vibrator }\end{array}$ & 10 & 86 \\
\hline
\end{tabular}

wide plate units and one $1.6 \mathrm{~m}$ wide plate unit on the bottom side of the barrel, as shown in Figure 10(c).

3.2. Assembly Jig Design. The assembly jig for the steel cylinders is divided into the upper and lower assembly jigs; they are integrated by assembly jig A. As shown in Figure 11, the horizontal base and vertical support of assembly jig A consist of an H-beam (HW $200 \times 200 \times 8 \times 12$ ). A steel plate with a $12 \mathrm{~mm}$ thickness and a $15 \mathrm{~m}$ arc radius is placed above the beam.

The lower assembly jig contains eight $11772 \times$ $3200 \times 22 \mathrm{~mm}$ steel plates and one $11772 \times 3200 \times 22 \mathrm{~mm}$ steel plate welded together, as shown in Figure 12. To ensure the integrity and reliability of the steel plates and assembly jig, several assembly jigs A are placed under the steel plates. These assembly jigs A are welded together by C20 steel channels.

Similarly, the upper assembly jig contains three $11772 \times 3200 \times 22 \mathrm{~mm}$ steel plates and one $11772 \times$ $3200 \times 22 \mathrm{~mm}$ steel plate welded together, as shown in Figure 13. Four assembly jigs A are placed under the steel
TABLE 5: Noise influence range of construction machines.

\begin{tabular}{lcccc}
\hline \multirow{2}{*}{ Noise source } & \multicolumn{2}{c}{$\begin{array}{c}\text { Noise threshold } \\
(\mathrm{dB}(\mathrm{A}))\end{array}$} & \multicolumn{2}{c}{$\begin{array}{c}\text { Standard } \\
\text { distance }(\mathrm{m})\end{array}$} \\
& Day & Night & Day & Night \\
\hline Piling machine & 70 & 55 & 89 & 500 \\
Bulldozer & 70 & 55 & 50 & 283 \\
Loader machine & 70 & 55 & 36 & 200 \\
Cement vibrator & 70 & 55 & 63 & 353 \\
\hline
\end{tabular}

plates. As with the lower assembly jig, these assembly jigs A are welded together by $\mathrm{C} 20$ steel channels.

The assembly jig for the auxiliary cells is integrated by several assembly jigs B, as shown in Figure 14. The horizontal base and vertical support of assembly jig B consist of an H-beam (HW $200 \times 200 \times 8 \times 12$ ). A $12 \mathrm{~mm}$ thick steel plate is placed above the beam to form an arc with an $8635 \mathrm{~mm}$ radius.

The assembly jig of the auxiliary cells contains ten $14017 \times 3200 \times 16 \mathrm{~mm}$ steel plates and one $14017 \times 3200 \times 16 \mathrm{~mm}$ steel plate welded together, as shown in Figure 15. Two assembly jigs B are placed under the steel plates. These assembly jigs B are welded together by C20 steel channels.

For the overall steel cylinder assembly jig, an $800 \times 20$ steel column is employed as the upright column and a $426 \times 12$ pipe is selected as a secondary beam and a diagonal brace, as shown in Figure 16. All the steel plates are Q345B.

\section{Safety Analysis}

Numerical simulations provide an effective way to confirm the safety of steel cylinder construction prior to 


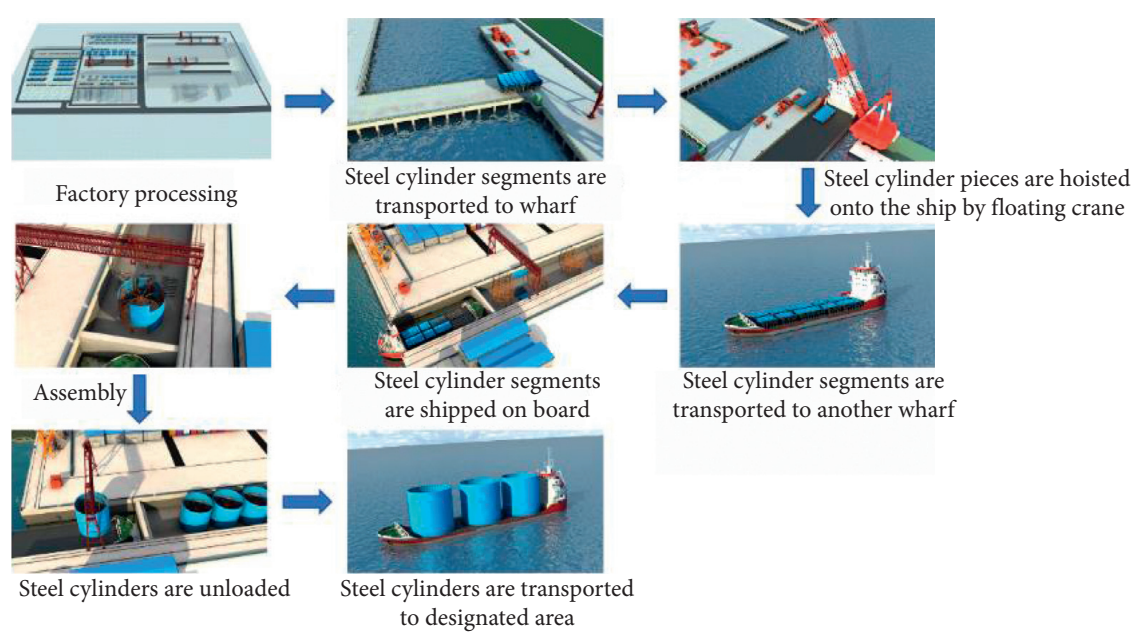

Figure 7: Production and transportation process of steel cylinders.

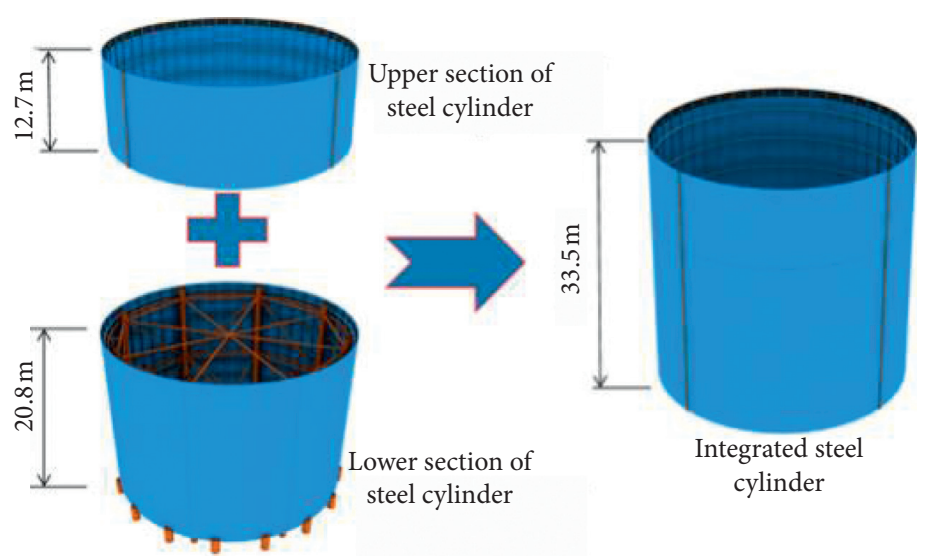

FIGURE 8: Horizontal segments.

actual construction [19]. Owing to severe weather conditions during the SSRA construction period, including the occurrence of typhoons, great attention should be paid to the steel cylinders. If the steel cylinders can still fulfill the strength requirements under an intensely adverse condition, the overall safety of the process can be certified. To this end, the finite element software ANSYS (ANSYS, Inc., Canonsburg, PA, USA) is employed to build a numerical model of the steel cylinder. Furthermore, the steel cylinders are stored near the wharf after assembly for convenient shipping. Self-propelled modular trailers (SPMTs) are employed to transport the steel cylinders from wharf to ship. During this process, $1.4 \mathrm{~m}$ high blocks are set on the steel cylinder assembly jig to ensure transportation reliability. Due to the large weight and height of the steel cylinders, the ANSYS finite element model is also employed to confirm transportation safety and investigate the safety repertory of the steel cylinder.

According to the design code for steel structures (GB 50017-2017), the load combination $G_{c}$ can be calculated according to the following formulations:

$$
\begin{aligned}
G & =8000 \mathrm{kN}(\text { the maximum weight of the steel cylinder }), \\
w_{k} & =\beta_{z} \mu_{s} \mu_{z} w_{o}, \\
F_{w y} & =w_{k} \times A_{1}, \\
G_{c} & =1.2 \times G+1.4 \times\left(F_{w y}+F_{q x}\right),
\end{aligned}
$$

where $G$ is the dead load; $w_{k}$ is the wind load; $\beta_{z}$ is the wind vibration coefficient, value $=1 ; \mu_{s}$ is the wind load shape coefficient for a cylindrical shape, value $=0.6 ; \mu_{z}$ is the wind pressure variation coefficient, value $=1.52 ; w_{o}$ is the basic wind pressure for a maximum wind speed of $20 \mathrm{~m} / \mathrm{s}$, value $=0.25 \mathrm{kN} / \mathrm{m}^{2} ; A_{1}$ is the horizontal windward area, value $=39 \mathrm{~m} \times 30 \mathrm{~m}=1170 \mathrm{~m}^{2} ; F_{w y}$ is the transverse wind pressure; and $F_{q x}$ is the unbalanced horizontal traction. The maximum single-side traction of the SPMT arranged at the bottom of the steel cylinder is $6 \times 12=72$ and $t=720 \mathrm{kN}$, and the unbalanced horizontal traction value is $360 \mathrm{kN}$. Table 6 lists the simulation model load combinations, including the load specifications. 


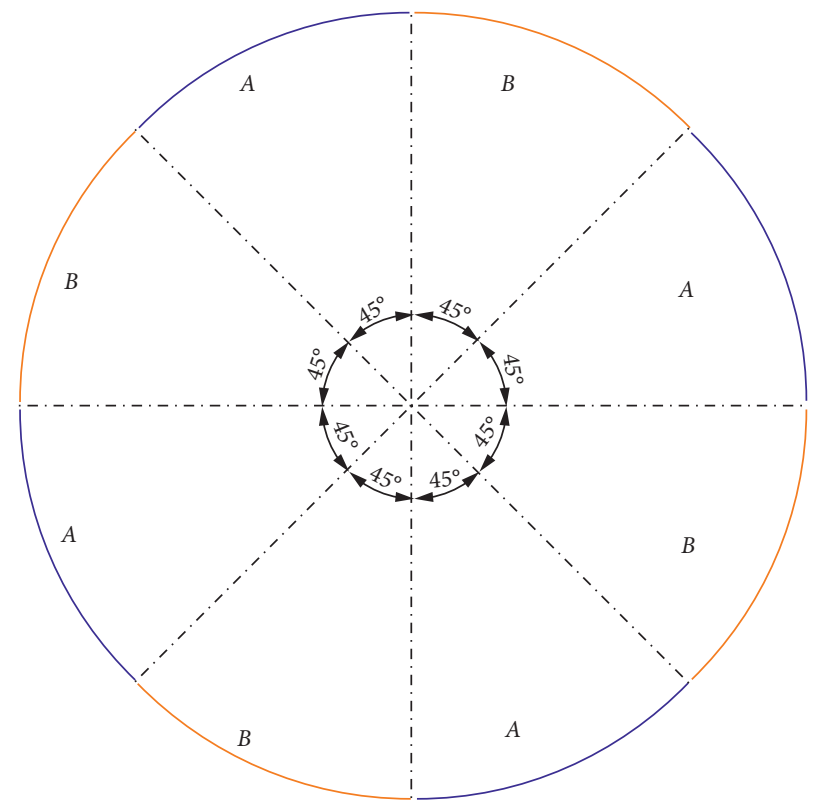

(a)

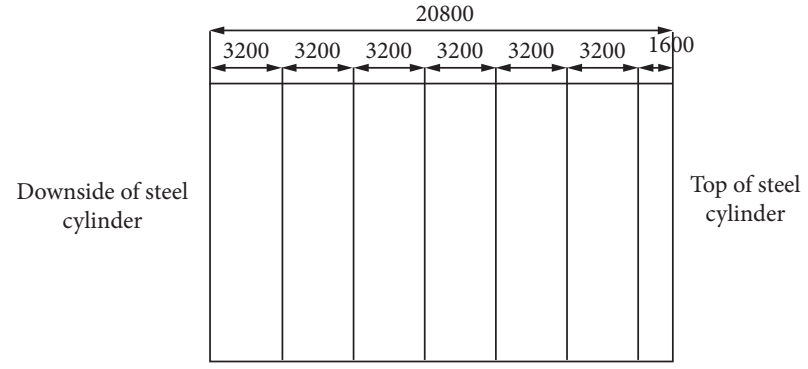

(b)

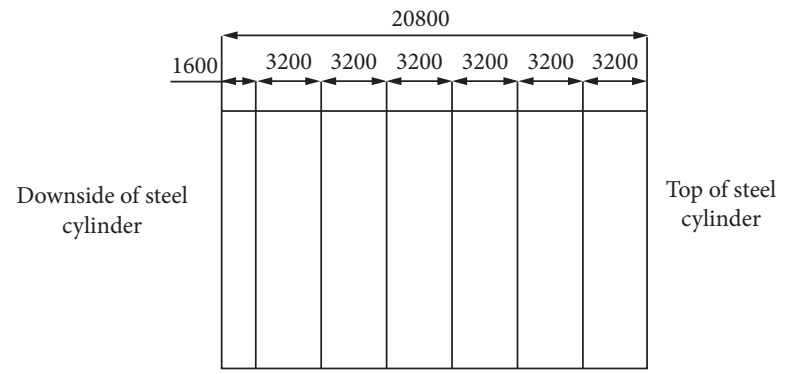

(c)

FIGURE 9: Lower section segments: (a) section segments (top view); (b) type A cylinder design (side view); (c) type B cylinder design (side view).

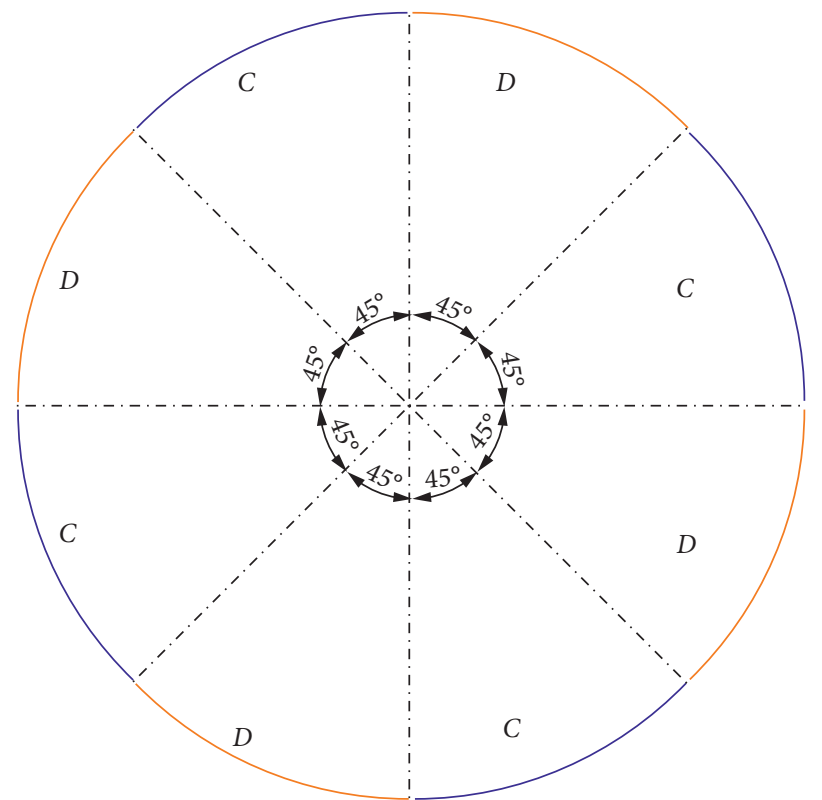

(a)

FIgURE 10: Continued. 


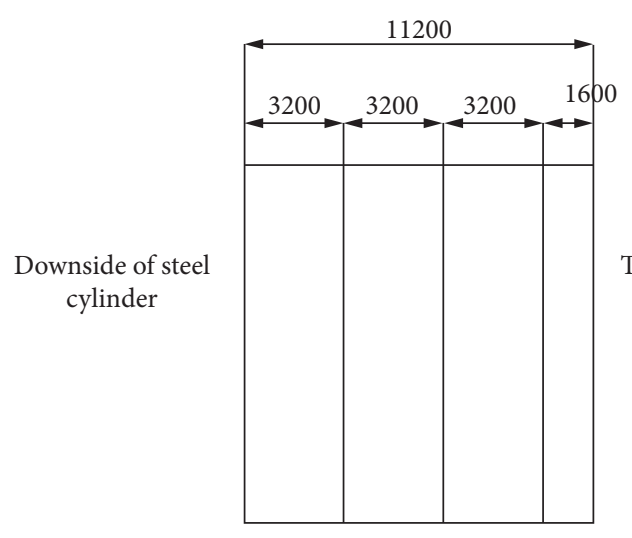

(b)

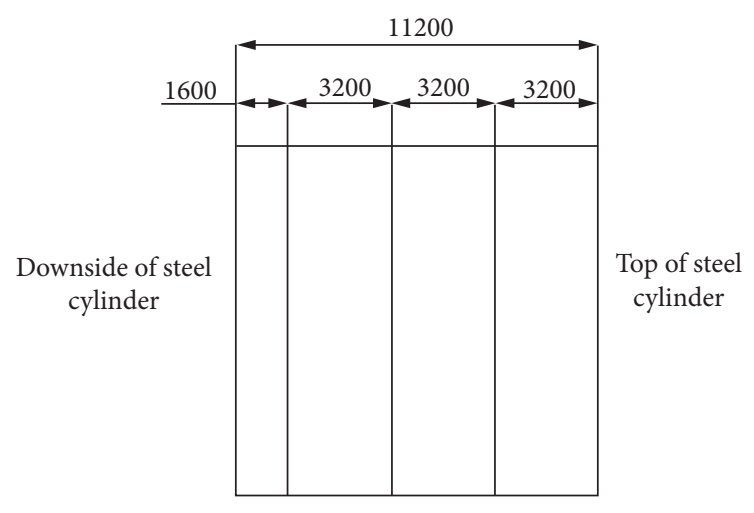

(c)

FiguRE 10: Upper section segments: (a) section segments (top view); (b) type C cylinder design (side view); (c) type D cylinder design (side view).

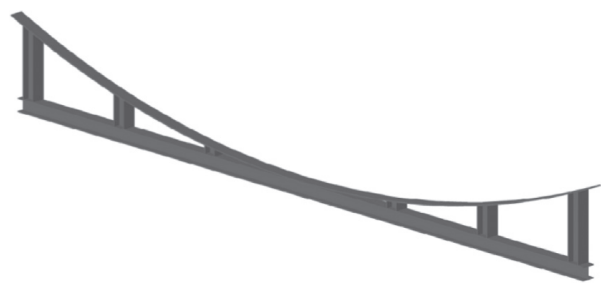

(a)

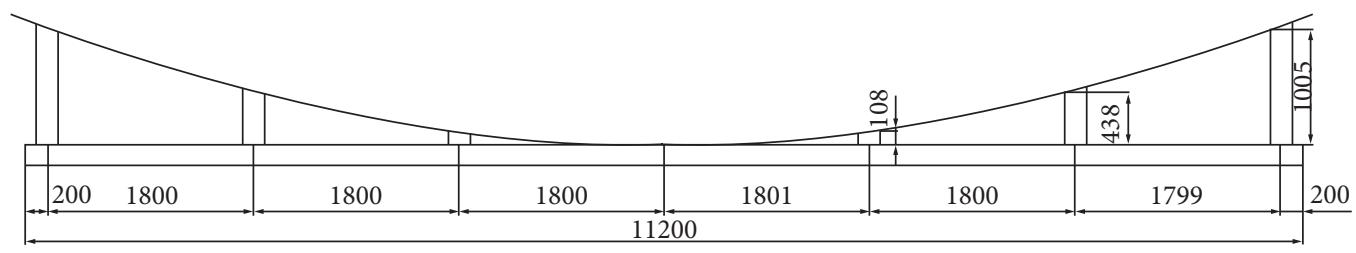

(b)

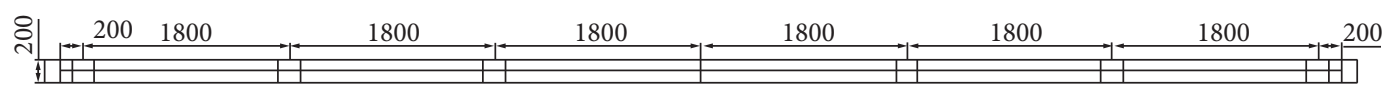

(c)

Figure 11: Assembly jig A: (a) 3D model; (b) side view; (c) top view.

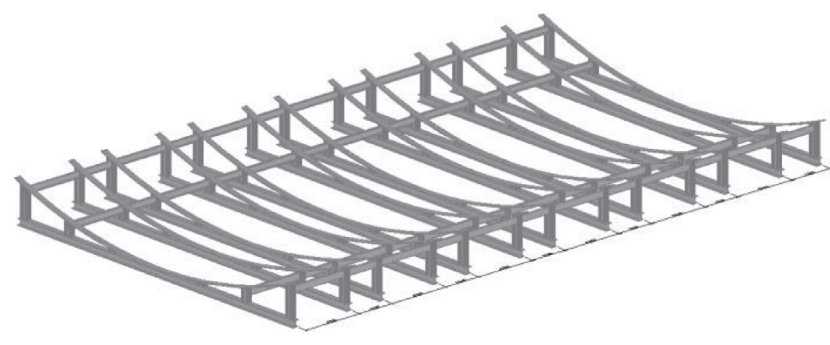

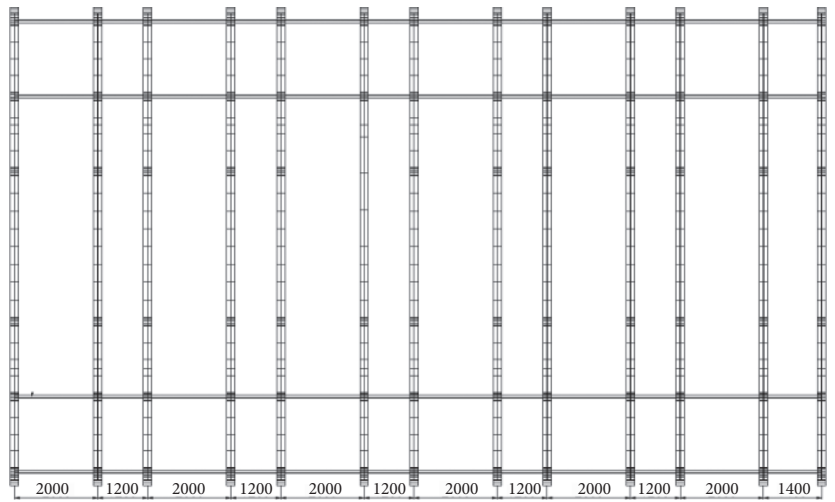

(b)

(a)

Figure 12: Lower assembly jig: (a) 3D model; (b) top view. 

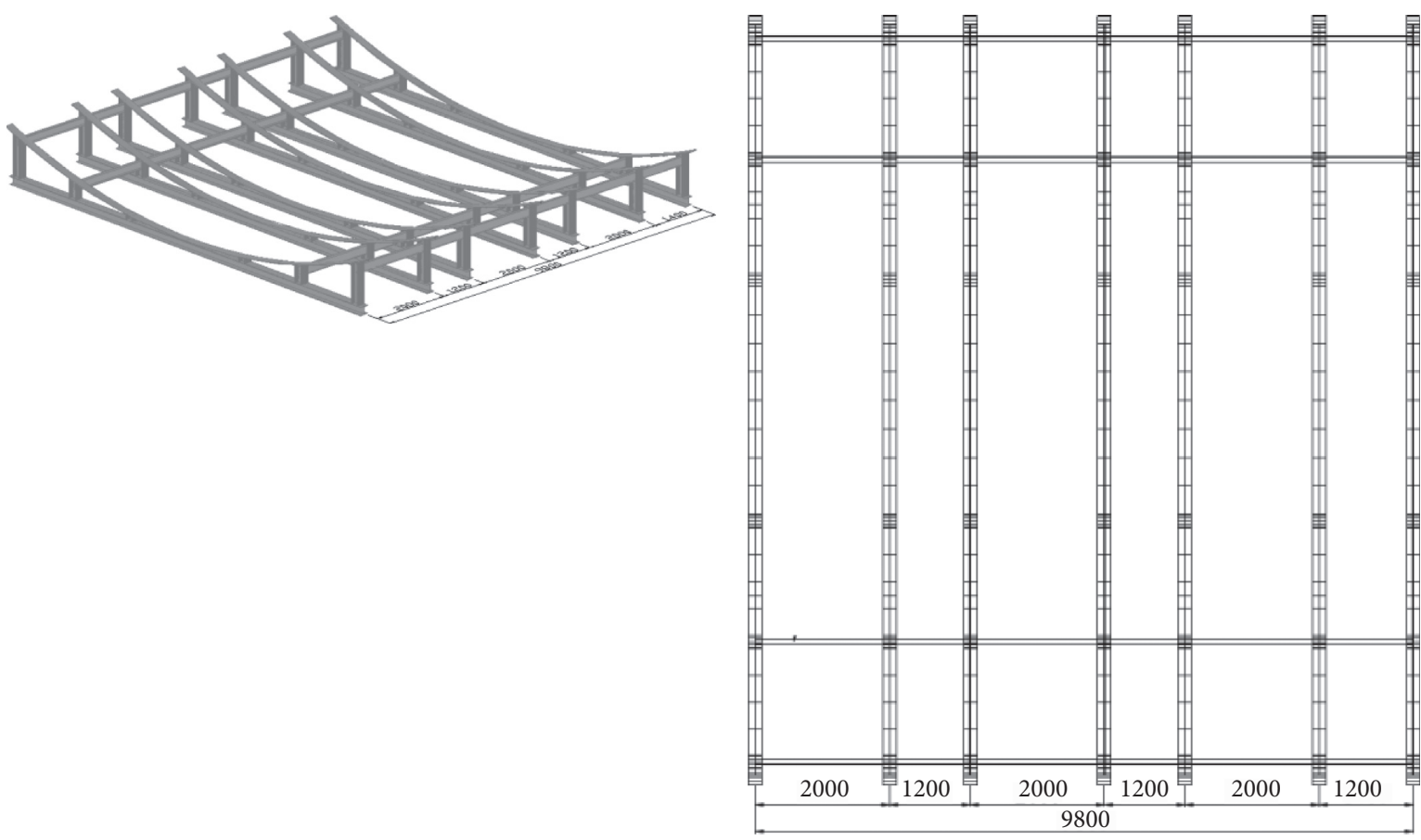

(a)

(b)

FIgURE 13: Upper assembly jig: (a) 3D model; (b) top view.

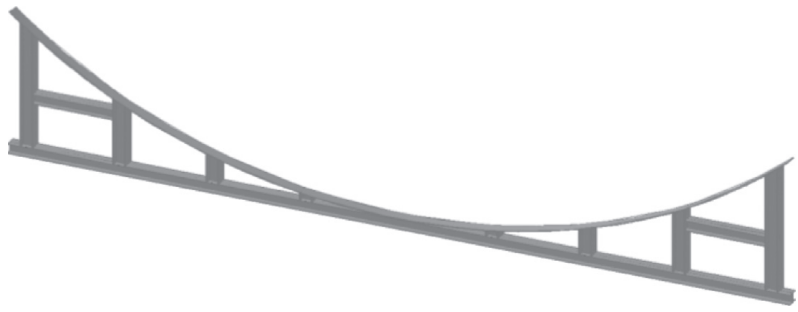

(a)

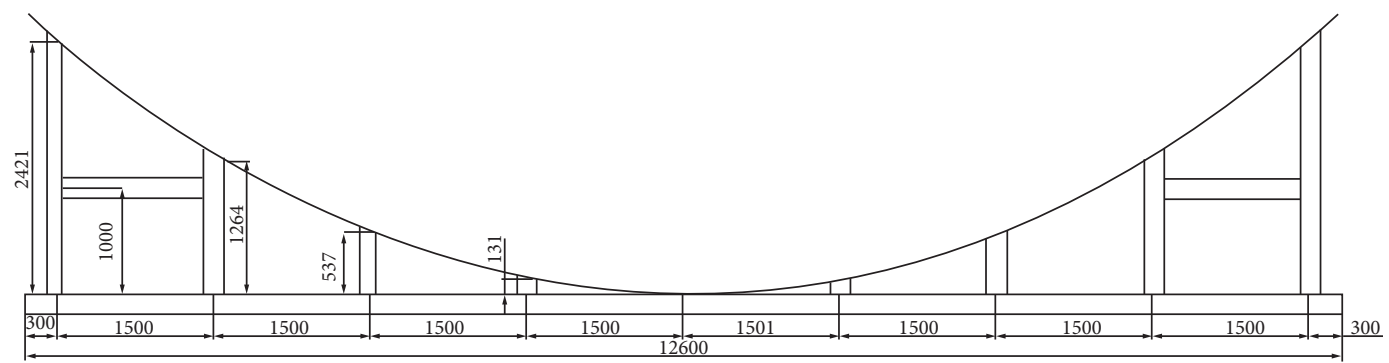

(b)

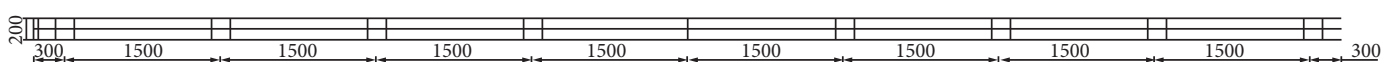

(c)

Figure 14: Assembly jig B: (a) 3D model; (b) side view; (c) top view.

Based on the numerical model depicted in Figure 17, a simulation is conducted to investigate the stress field distribution in the steel cylinder, which is followed by a strength test. Thick plate elements were used to model the cylinder wall and annular transverse ribs, and beam elements were used to simulate T-shaped longitudinal ribs. Figure 18 presents the maximum stress occurring at the bottom of the steel cylinder, which is connected to a SPMT. Figure 19 indicates the maximum displacement occurring on the top of the steel cylinder. The maximum horizontal displacement observed was $62 \mathrm{~m}$, and the maximum vertical displacement was $32 \mathrm{~m}$ (vertical displacement/1.4). 


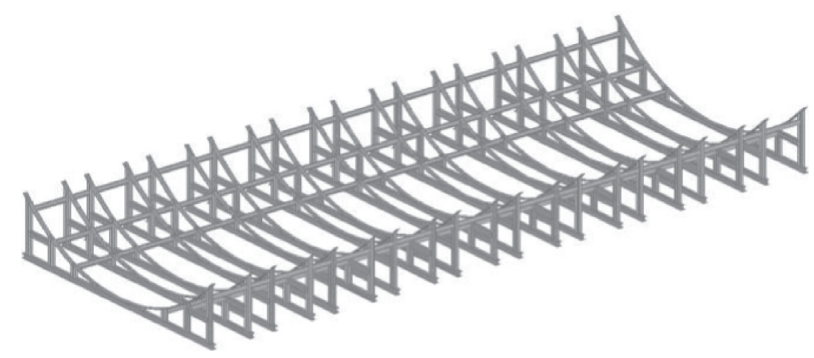

(a)

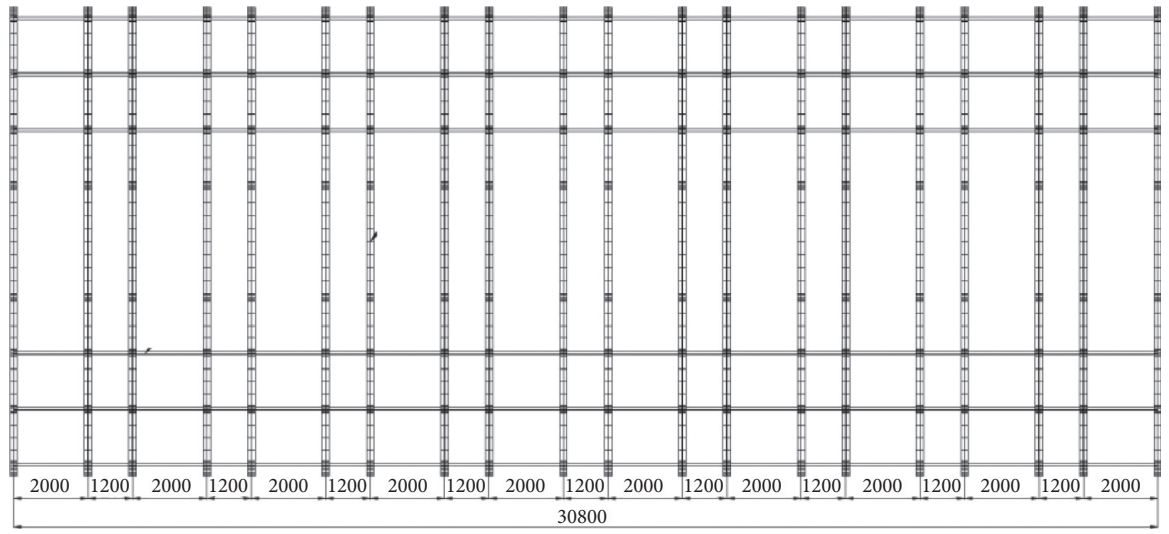

(b)

Figure 15: Assembly jig for auxiliary cell: (a) 3D model; (b) top view.

Table 7 indicates that the steel cylinder exhibits sufficient safety repertory and fulfills the stress and displacement requirements in such extremely unfavorable conditions; by extension, this verifies the reliability of the steel cylinder safety system design discussed in Section 3.

\section{Safety Control Process}

Based on the safety system analysis detailed in Section 5, the steel cylinder has a significant impact on the safety of sea reclamation construction. Nevertheless, taking reasonable construction measures can control the steel cylinder vibration and sinking process; some practical control measures are described next.

5.1. Transportation Control. Before the steel cylinders are shipped, they are transported by SPMTs to the wharf. Because climate conditions can vary rapidly, weather monitoring should be prioritized. The hydrologic data of the wharf indicate that the wharf surface elevation is $+5.5 \mathrm{~m}$, the seafloor depth is $-10.8 \mathrm{~m}$, the average high water level is $+2.76 \mathrm{~m}$, and the average low water level is $+1.1 \mathrm{~m}$. Thus, the height from the wharf to the water surface at the minimum low water level is $4.4 \mathrm{~m}$, and the height from the wharf to the water surface at the peak high water level is $2.74 \mathrm{~m}$. Therefore, the barge carries the cargo, and the rear freeboard should be between 2.74 and $4.4 \mathrm{~m}$ to satisfy the shipment requirements. According to Tables 8 and 9, when the height from the wharf to the water surface reaches $3.5 \mathrm{~m}$ and the tide height reaches $174 \mathrm{~cm}$, steel cylinders can be transferred to ships for transportation. This combination of factors occurs at 17:00, which was selected as the optimum time for transportation.

Three steel cylinders are shipped per vessel, and each shipment takes 1.0-1.5 days. After arriving at the designated position on the barge deck, the steel cylinders loaded on the SPMT are unloaded onto temporary piers on the deck. Finally, the steel cylinders are integrated.

5.2. Steel Cylinder Vibration and Sinking Control. A monitoring and location system was employed to ensure the safety and accuracy of the steel cylinder vibration and sinking process, and the system is shown in Figure 20. To establish a relative position reference for the comprehensive monitoring and location system, scale lines, such as $0^{\circ}$ and $180^{\circ}$ lines, and height lines are drawn on the steel cylinder (Figure 21). Fully automatic tracking total station and reflection prism can measure the angle and distance of steel cylinder inclination, and a level gauge can measure the steel cylinder verticality. Figure 22 shows that the system can monitor horizontal and vertical position information in real time.

During the vibration and sinking stage, it is critical to ensure the accurate positioning of three different ships, namely, the positioning, floating crane, and transport ships. The coordinates of the positioning ship can be calculated accurately according to the coordinates of the steel cylinder vibration position, cylinder diameter, positioning ship size, and the dimensions of the positioning guide frame. Therefore, the positioning ship can be placed in the working 


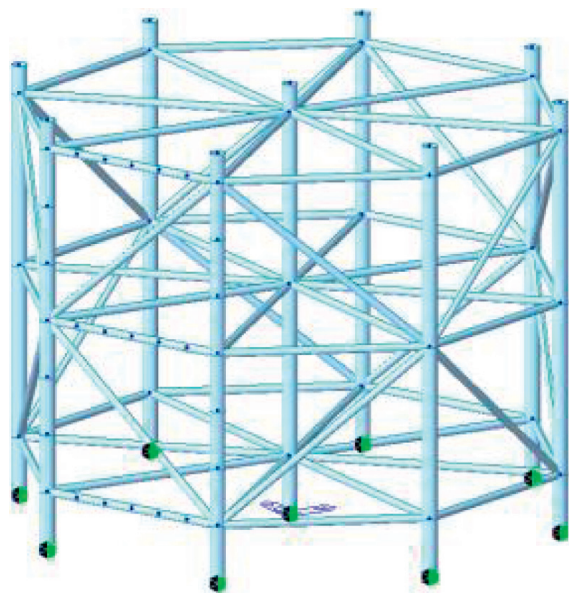

(a)

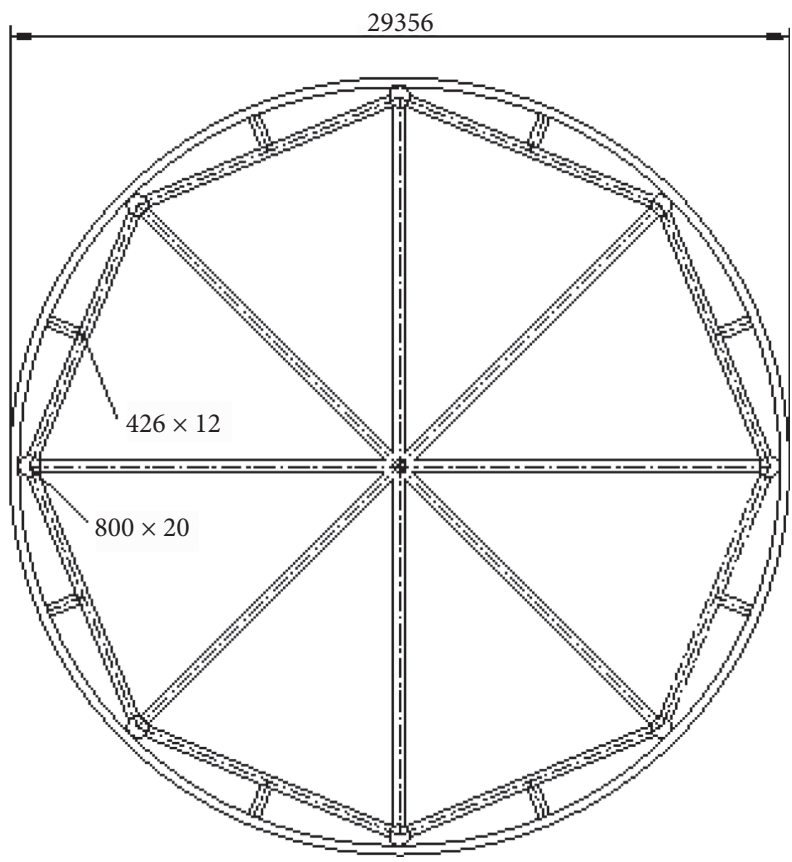

(b)

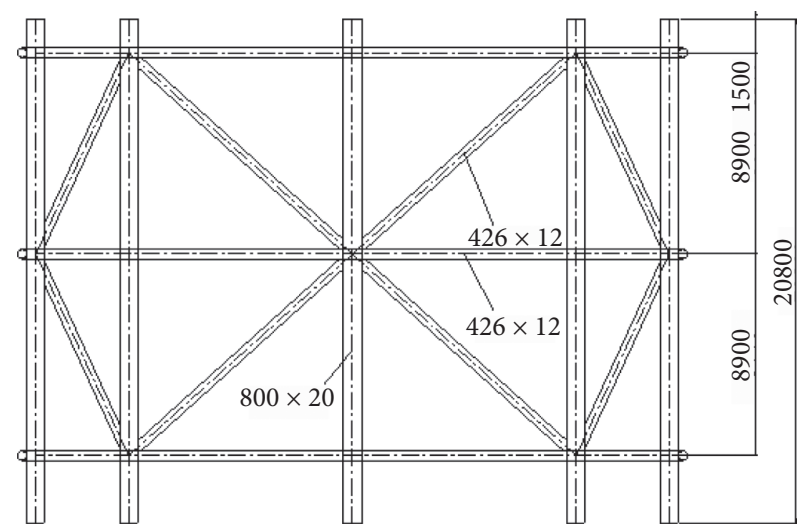

(c)

FIGURE 16: Overall assembly jig for the steel cylinders: (a) 3D model; (b) top view; (c) side view.

TABLE 6: Load combinations.

\begin{tabular}{lc}
\hline Item & Value $(\mathrm{kN})$ \\
\hline Dead load & 8000 \\
Wind load & 266.8 \\
Uneven horizontal traction & 360 \\
Load combination & 10477.52 \\
\hline
\end{tabular}

area through the tug and its own anchor cable. Based on the vibration hammer group weight, steel cylinder weight, and lifting characteristic curve of the crane ship, the coordinates of the floating crane ship can be calculated. The floating crane ship is positioned through the tug and its own anchor cable. The position of the transport ship can be determined according to the floating crane working radius, and the three

\section{Elements}

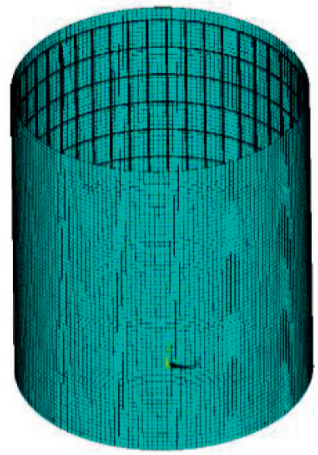

Figure 17: Steel cylinder numerical simulation model mesh. 


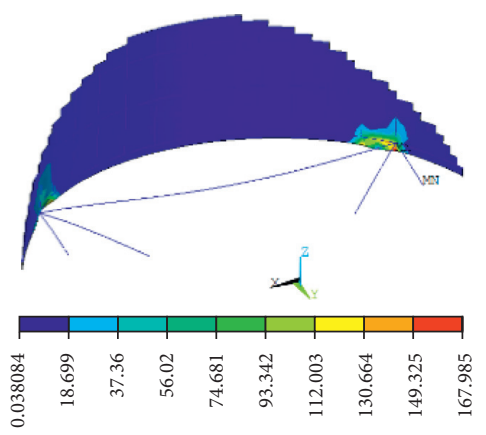

FIGURE 18: Stress distribution.

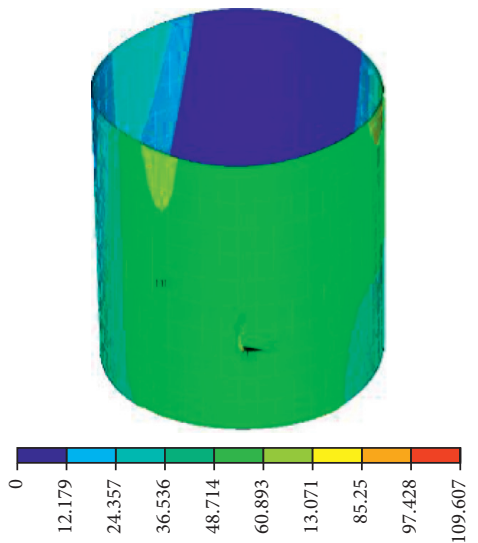

(a)

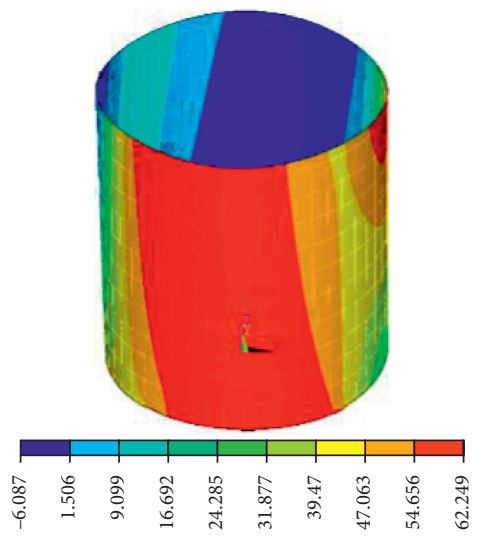

(b)

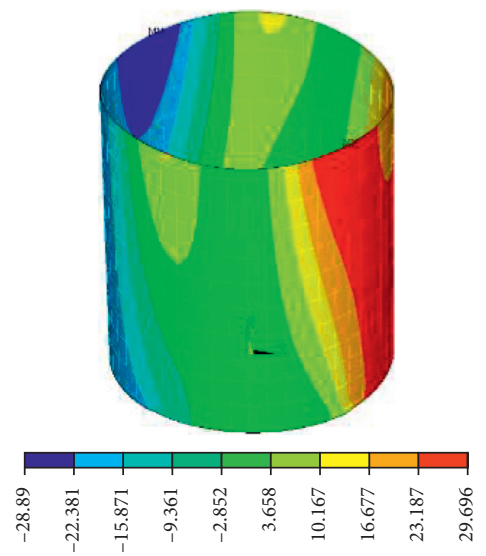

(c)

Figure 19: Results of steel cylinder displacement test: (a) displacement distribution; (b) horizontal displacement distribution; (c) vertical displacement distribution.

TABLE 7: Numerical simulation results.

\begin{tabular}{lcc}
\hline Item & Simulation value & Checking criteria \\
\hline Stress & $168 \mathrm{MPa}$ & $\leq 295 \mathrm{MPa}$ (tensile bending strength of Q345B steel) \\
Displacement & $110 \mathrm{~mm}$ & $\leq$ steel pipe diameter/200 \\
\hline
\end{tabular}

TABle 8: Tide report (from 00:00 to 11:00).

\begin{tabular}{|c|c|c|c|c|c|c|c|c|c|c|c|c|}
\hline Time & 00:00 & 01:00 & 02:00 & 03:00 & 04:00 & 05:00 & 06:00 & 07:00 & 08:00 & 09:00 & $10: 00$ & $11: 00$ \\
\hline Tide height $(\mathrm{m})$ & 187 & 198 & 205 & 208 & 209 & 208 & 206 & 205 & 208 & 214 & 220 & 224 \\
\hline Height from wharf to water surface $(\mathrm{m})$ & - & 一 & - & - & 一 & - & - & - & 3.1 & 3 & 2.95 & 2.91 \\
\hline
\end{tabular}

TABle 9: Tide report (from 12:00 to 23:00).

\begin{tabular}{|c|c|c|c|c|c|c|c|c|c|c|c|c|}
\hline Time & $12: 00$ & 13:00 & $14: 00$ & $15: 00$ & $16: 00$ & $17: 00$ & $18: 00$ & 19:00 & $20: 00$ & $21: 00$ & $22: 00$ & $23: 00$ \\
\hline Tide height $(\mathrm{m})$ & 226 & 222 & 214 & 202 & 188 & 174 & 163 & 156 & 155 & 166 & 182 & 201 \\
\hline Height from wharf to water surface $(\mathrm{m})$ & 2.85 & 2.97 & 2.99 & 3.25 & 3.44 & 3.5 & 3.65 & 3.9 & 3.92 & 3.7 & 一 & - \\
\hline
\end{tabular}

working ships are kept relatively parallel to each other, as shown in Figure 23.

Hammers clamp the steel cylinders; during this process, a hammer set should be positioned on the right side above the steel hammer. After ensuring that the hammer set is relatively stable, the hook is slowly loosened until the steel cylinder enters the guide groove of the hydraulic fixture. The vibrating hammer set is then adjusted to stick the middle fixture of the hammer to the baffle, which is set up previously on the cylinder wall, as shown in Figure 24.

Attention should be paid to the perpendicularity of the steel cylinders during the process of sinking them in the sea. If the inclination of the steel cylinder becomes large because of rapid eddy circulations, the sinking process should be stopped immediately; the process can be restarted when the inclination is reduced. The hook lifting weight should be 


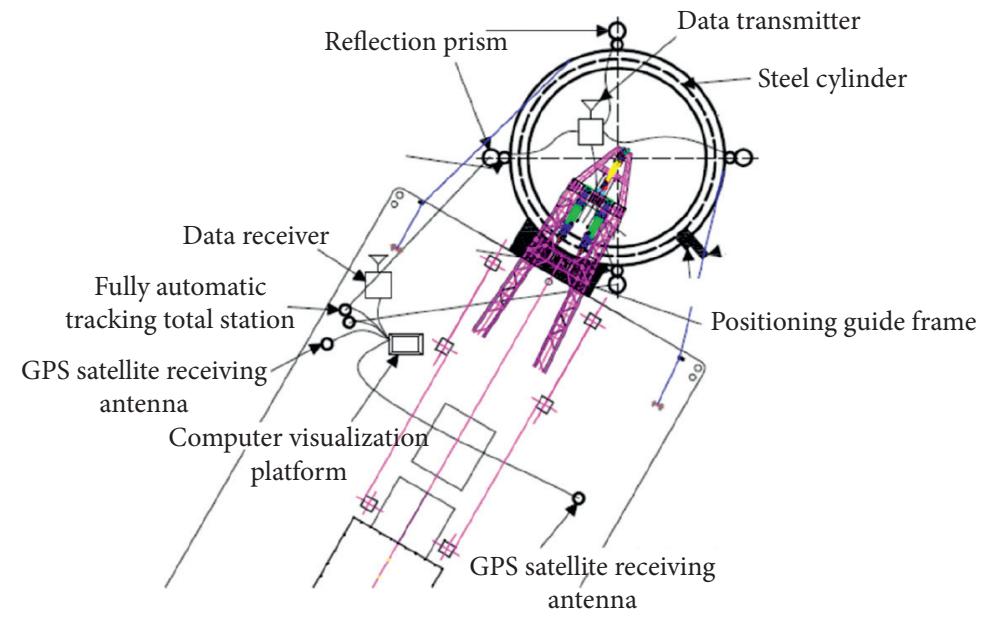

Figure 20: Monitoring and location system structure.

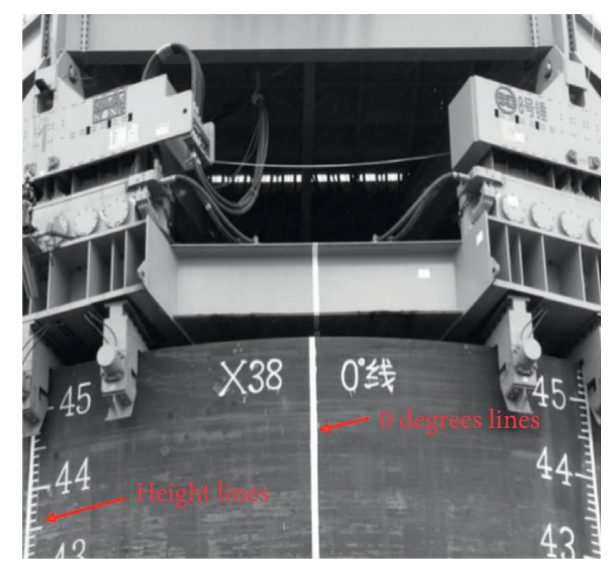

Figure 21: Scale lines in the steel cylinder.

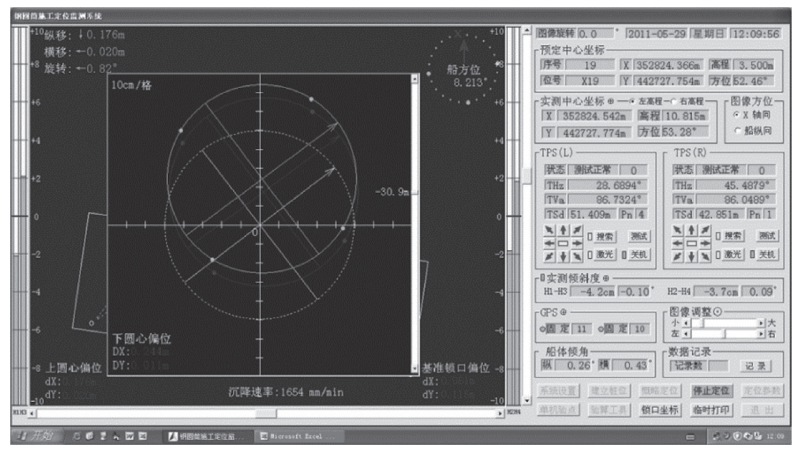

Figure 22: Monitoring and location system visualization platform.

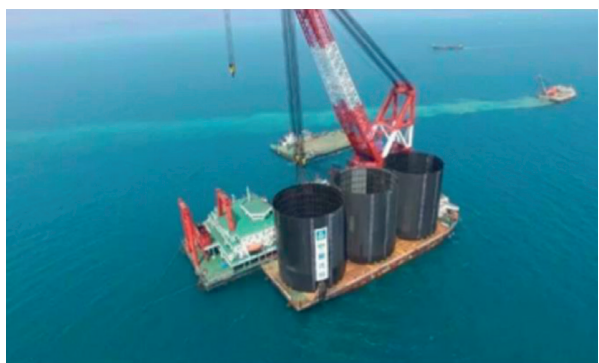

FIgure 23: Positions of the three working ships.

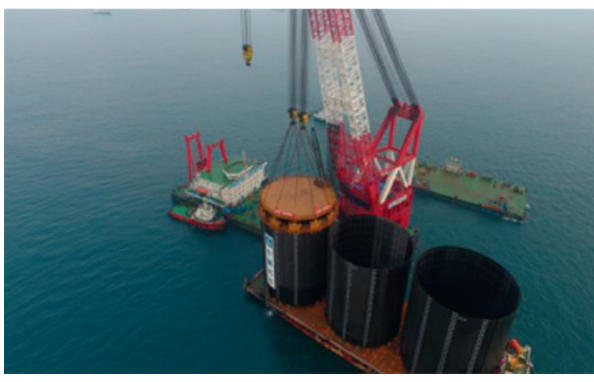

Figure 24: Clamping of steel cylinder.

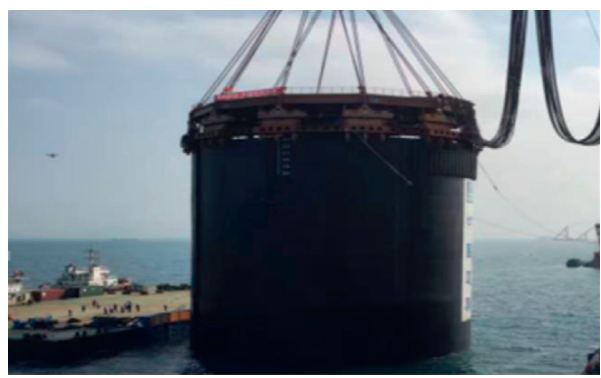

Figure 25: Steel cylinder sinking.

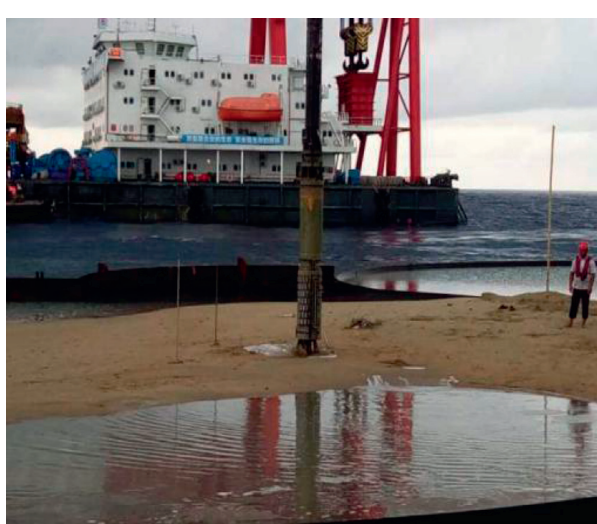

FIGURE 26: Backfilling sand experiment. 
TABLE 10: Sand verification criteria.

\begin{tabular}{lc}
\hline Item & Verification criteria \\
\hline $\begin{array}{ll}\text { Internal friction } \\
\text { angle }\end{array}$ & $\geq 32^{\circ}$ \\
Clay content & $\leq 5 \%$ \\
Permeate coefficient & $\geq 5 \times 10^{-3} \mathrm{~cm} / \mathrm{s}$ \\
Sand diameter & Sand diameter exceeding $2 \mathrm{~mm}$ should not exceed $50 \%$ of the total mass, and sand diameter exceeding $0.075 \mathrm{~mm}$ \\
& should exceed $50 \%$ of the total mass \\
\hline
\end{tabular}

strictly controlled so that the hook can maintain a certain lifting force to ensure the steel cylinder stability, as shown in Figure 25.

5.3. Auxiliary Cell Vibration and Sinking Control. After the steel cylinder is sunk, the auxiliary cell should also be sunk to connect different steel cylinders together and maintain stability. The auxiliary cell position can be adjusted by changing its upper and lower chord lengths. Hangers are set at the top and bottom of the auxiliary cell. The main hook of the floating crane is connected with the top main hanger using steel wire rope, while the secondary hook is connected with the bottom subhanger also using steel wire rope. After lifting the auxiliary cell horizontally from the transport ship, it is rotated to the top of the steel cylinder; the main hook is slowly lifted, and the secondary hook is lowered until the auxiliary cell is upright. Finally, the steel cylinder and auxiliary cell are connected.

5.4. Backfilling Sand Quality Control. After the steel cylinder is sunk, medium-coarse sand should be backfilled to form the land. To ensure the quality of backfilling sand, experiments should be conducted prior to construction. A square area of $30 \times 30 \mathrm{~m}$ was selected for these experiments. Vibration holes are arranged in equilateral triangles, and a hole spacing of 3.0, 3.5, and $4.0 \mathrm{~m}$ is adopted to conduct the tests, as shown in Figure 26. Table 10 lists the verification standards in response to the aforementioned backfilling sand indexes.

A high-pressure water cannon is employed to backfill the sand (Figure 27). During this process, workers are required to keep moving the blowpipe to guarantee that the sand water mixture flows evenly.

\section{Safety Effect Evaluation}

According to the reasonable countermeasures adopted based on the numerical simulation analysis, which was conducted with a set of valid assumptions, the steel cylinder vibration and sinking process were accomplished on schedule. These results indicate that the steel cylinder transportation, vibration, and sinking were stable. In addition, the sand backfilling process can meet the quality control criteria. Therefore, the safety management approach for the complete process of sea reclamation construction is proven to be reliable and feasible.

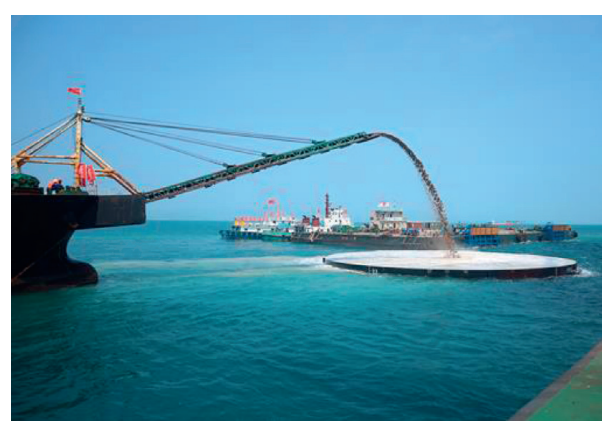

FIGURE 27: Backfilling sand.

\section{Conclusions}

In recent years, the safety management of sea reclamation construction has raised widespread concerns owing to its close relationship with the issues of public safety, particularly in the process of steel cylinder vibration and sinking. This process is likely to cause shipment accidents and in some instances results in human casualties. To ensure the safety of this process in complex and hazardous working environments, reliable design schemes for the steel cylinder and assembly jig are proposed in this paper. The SSRA in Hainan Province, China, is used as a case study. The results verify the feasibility of the proposed method, which could be applied to other similar sea reclamation construction projects. In light of these results, the following conclusions are drawn:

(1) The schemes for steel cylinder transportation should be methodically established based on site conditions during the vibration and sinking processes, particularly in complex sea conditions. Owing to the height and weight of the steel cylinder, construction difficulty increases; therefore, the steel cylinder is divided into several segments that can be manufactured independently. Additionally, integrating these segments is also a challenge; so, assembly jigs are carefully designed to meet the construction requirements.

(2) Numerical analysis simulations are determined to be a reliable method for the safety management control of complex projects. Nevertheless, time and resources may be misused while analyzing the overall process in advance. To establish a balance between safety and economic efficiency, numerical simulation methods should focus on the most unfavorable 
conditions and stages of the construction process. In the case of the SSRA, priority should have been given to the steel cylinders. It is thus essential to inspect the stress and displacement distributions in the steel cylinders.

(3) Establishing an accurate location system is an important technical issue in the safety control of vibration and sinking processes, particularly in harsh working environments and during extreme events, such as typhoons. Considerable deviation exists due to the fact that a typhoon may have adverse impacts on the location system; therefore, the steel cylinder vibration and sinking processes should be conducted carefully, and more attention should be paid to dynamic changes.

Despite its demonstrated advantages, the proposed systemic approach has some limitations. First, effective measures have been adopted to guarantee safety during the transportation and vibration of steel cylinders; however, more advanced innovation technologies should be developed. For example, health-monitoring technology, which integrates sensor technology and data mining, could be used to examine the dynamic safety performance during the steel cylinder transportation and vibration processes. Second, by adopting numerical analysis techniques, the safety performance of steel cylinder could be guaranteed even under the most intensely adverse conditions. However, a higher safety repertory will increase the steel cylinders' production costs. Therefore, an optimal design scheme for steel cylinders needs to be explored in future works to ensure the safety repertory of steel cylinders as well as cost reduction by adopting multiobjective optimization. According to the marine ecosystem impact assessment, some original marine organism habitats, such as benthos, fish eggs, and larvae, may be negatively affected. New marine organisms could be placed in the affected marine ecosystem to make up for the absence and damage; some of these marine organisms recover quickly and rebuild their communities. Furthermore, foundation trench dredging and dumping areas should be accurately positioned and operated to avoid repeated operation in the same general area, thus reducing the disturbance intensity on the marine organism habitats that are located in the construction site surrounding areas. Coral reefs near the construction area should be removed and transported to another suitable sea area for further protection. During the construction period, the number and route of construction ships should be strictly planned to prevent the coral reef habitat from being impacted. Considering the fact that shoreline erosion and deposition reduces coral reef habitats, artificial beach nourishment and detached breakwaters should be implemented to prevent the coral reef habitat from being occupied. Additionally, materials used in cofferdam construction should be carefully selected because coral reef can live on certain suitable materials and potentially increase their habitat. Smart construction is an alternative that could be explored in the future, but one of its key challenges is connecting the visual and physical spaces. Digital twin technologies could integrate the physical and virtual data throughout the construction project lifecycle, which leads to a massive volume of data that could be processed by advanced analytics. In future studies, we plan to apply digital twin technologies to promote the integration between visual and physical models. More advanced simulation analysis will be employed to guarantee the safety of future sea reclamation construction.

\section{Data Availability}

All data used to support the findings of this study will be available from the corresponding author on request.

\section{Conflicts of Interest}

The authors declare that there are no conflicts of interest.

\section{Acknowledgments}

This work was supported by the Ministry of Humanities and Social Sciences of China (Grant No. 20YJAZH141) and Tianjin Science and Technology Planning Project (Grant No. 15ZXHLSF00040).

\section{References}

[1] X. Q. Kou, A. M. Liu, and J. F. Hou, "Study on deformation of steel cylinder during artificial island construction," Advanced Materials Research, vol. 671-674, pp. 296-301, 2013.

[2] O. T. Gudmestad, "Marine construction and operation challenges in the Barents Sea," Ship Technology Research, vol. 60, no. 3, pp. 128-137, 2015.

[3] R. K. Wysocki, Effective Project Management: Traditional, Agile, Extreme, Wiley, Hoboken, NJ, USA, 2011.

[4] D. N. C. Lai, M. Liu, and F. Y. Y. Ling, "A comparative study on adopting human resource practices for safety management on construction projects in the United States and Singapore," International Journal of Project Management, vol. 29, no. 8, pp. 1018-1032, 2011.

[5] B. Corovic and P. Djurovic, "Research of marine accidents through the prism of human factors," Promet-Traffic-Transport, vol. 25, pp. 369-377, 2013.

[6] E. Akyuz, "A hybrid accident analysis method to assess potential navigational contingencies: the case of ship grounding," Safety Science, vol. 79, pp. 268-276, 2015.

[7] E. Akyuz, "A marine accident analysing model to evaluate potential operational causes in cargo ships," Safety Science, vol. 92, pp. 17-25, 2017.

[8] K. M. Abujaafar, "Quantitative human reliability assessment in Marine Engineering operations," Ph.D. thesis, Liverpool John Moores University, Liverpool, UK, 2012.

[9] E. Akyuz, "Quantitative human error assessment during abandon ship procedures in maritime transportation," Ocean Engineering, vol. 120, pp. 21-29, 2016.

[10] S.-Q. Tong, N. Wang, and N.-Q. Song, "Emergency evacuation capability evaluation and optimization for an offshore airport: the case of Dalian Offshore Airport, Dalian, China," Safety Science, vol. 92, pp. 128-137, 2017.

[11] H. Karahalios, "The contribution of risk management in ship management: the case of ship collision," Safety Science, vol. 63, pp. 104-114, 2014. 
[12] C. Chauvin, S. Lardjane, G. Morel, J.-P. Clostermann, and B. Langard, "Human and organisational factors in maritime accidents: analysis of collisions at sea using the HFACS," Accident Analysis \& Prevention, vol. 59, pp. 26-37, 2013.

[13] A. Mazaheri, J. Montewka, J. Nisula, and P. Kujala, "Usability of accident and incident reports for evidence-based risk modeling - a case study on ship grounding reports," Safety Science, vol. 76, pp. 202-214, 2015.

[14] S. Guo, M. Peng, J. Ruan, and W. Wan, "Cause analysis of the fire and explosion during crude oil desulfurization in China," Journal of Loss Prevention in the Process Industries, vol. 26, no. 6, pp. 961-967, 2013.

[15] Y. F. Wang, M. Xie, K.-S. Chin, and X. J. Fu, "Accident analysis model based on bayesian network and evidential reasoning approach," Journal of Loss Prevention in the Process Industries, vol. 26, no. 1, pp. 10-21, 2013.

[16] J. Oh, S. Park, and O.-S. Kwon, "Advanced navigation aids system based on augmented reality," International Journal of E-Navigation and Maritime Economy, vol. 5, pp. 21-31, 2016.

[17] M. Grabowski, A. Rowen, and J. P. Rancy, "Evaluation of wearable immersive augmented reality technology in safetycritical systems," Safety Science, vol. 103, pp. 23-32, 2017.

[18] Y. Tan, Y. Song, J. Zhu, Q. Long, X. Wang, and J. C. P. Cheng, "Optimizing lift operations and vessel transport schedules for disassembly of multiple offshore platforms using BIM and GIS," Automation in Construction, vol. 94, pp. 328-339, 2018.

[19] C. Shi, M. Zhong, X. Nong, L. He, J. Shi, and G. Feng, "Modeling and safety strategy of passenger evacuation in a metro station in China," Safety Science, vol. 50, no. 5, pp. 1319-1332, 2012. 